\title{
Microscopic and Molecular Detection of Nosema ceranae in Honeybee Apis mellifera L. from Romania Status on pathogen worldwide distribution
}

\author{
NARCISA MEDERLE ${ }^{1}$, MARIA LUISA LOBOㄹ, SORIN MORARIUㄴ, FLORICA MORARIU³, GHEORGHE DARABUS ${ }^{1}$, \\ OVIDIU MEDERLE ${ }^{4 *}$, OLGA MATOS ${ }^{2}$ \\ ${ }^{1}$ Banat's University of Agricultural Sciences and Veterinary Medicine King Michael I of Romania, Parasitology/Mycology Department, \\ 119, Calea Aradului, 300645, Timisoara, Romania. \\ 2 Medical Parasitology Unit, Global Health and Tropical Medicine, GHTM, Instituto de Higiene e Medicina Tropical, IHMT, \\ Universidade Nova de Lisboa, UNL, Rua da Junqueira 100, 1349-009 Lisboa, Portugal. \\ ${ }^{3}$ Banat's University of Agricultural Sciences and Veterinary Medicine King Michael I of Romania, Faculty of Animal Science and \\ Biotechnology, Department of Biotechnology II, 119, Calea Aradului, 300645, Timisoara, Romania. \\ ${ }^{4}$ University of Medicine and Pharmacy, Faculty of Medicine Victor Babes, Microscopic Morphology Department, 2 Eftimie Murgu \\ Sq., 300041,Timisoara, Romania.
}

\begin{abstract}
Until now, in Romania, a country in southeastern Europe located on the Balkans Peninsula, information regarding the status on $A$. mellifera honey bee infection by Nosema spp. has not been published. The aims of the present study were to survey the occurrence and identification of Nosema spp. in A. mellifera honeybee colonies from 37 apiaries located in Arad, Caras-Severin and Timis Counties, Romania. Also, based on published literature an update on the distribution of $N$. ceranae infection among A. mellifera colonies worldwide was performed. Overall, a frequency of $55.1 \%$ (389/690) of Nosema infection was observed in the analyzed regions (ranging from 52\% to 66\%), by light microscopy. By PCR and DNA sequencing, $N$. ceranae was the only microsporidia identified. Nosema ceranae is clearly a novel, emergent pathogen of A.mellifera with potentially very serious effects on the individual and honeybee's colonies in Romania. Data obtained provide new and important information on N. ceranae geographic prevalence and distribution, and on its impact at colony level and/or its role in colony losses. The present study intends to contribute to highlight the importance of implementing prevention, treatment and control measures of honeybee nosemosis, in Romania.
\end{abstract}

Keywords: Apis mellifera honeybee; Microsporidia; Nosemosis; Nosema ceranae; Molecular characterization

For centuries, the importance of honeybees to honey and wax production and to the pollination of most crops is well recognized. Honey remains an importantinternational good with global production estimated at 1,07 million metric ton in 2007 (FAO, 2009), and almost fifty percent of leading global food commodities depend on honey bee pollination for either fruit or seed set (Klein etal., 2007). This insect is the most efficient pollinator for most crop monocultures around the world (McGregor et al,1976; Delaney et al., 2009). The western honeybee, Apis melliferaL., one of the most economically important species of the genus Apis, has been transported worldwide for beekeeping purposes from its native range in Europe, Africa and the Near East (Ruttner, 1988).

During the last decade multiple factors like pathogens, pesticides, and abiotic stressors have been identified associated with unusually high and inexplicable honeybee colony losses (Genersch etal., 2010; Ratnieks and Carreck, 2010; Cornman et al., 2012; Pettis et al., 2013). Among the pathogens characterized and discussed in this context are two microsporidian species from genus Nosema, (CoxFoster et al., 2007; Higes et al., 2008; Genersch, 2010) which infect adult honeybees (Bailey L, 1955), Nosema apis and Nosema ceranae. Both species are intracellular pathogens that are thought to represent very primitive, but highly specialized spore-forming fungi. Initially, nosemosis in A.mellifera was thought to be caused by a single species, Nosema apis Zander. However, in 1994, a microsporidium like $N$. apis, called $N$. ceranae was described in Eastern honey bee (Apis cerana Fabricius) from China (Fries et al., 1996). Transmission of Nosema in honeybee colonies is mainly via the fecal-oral route. The infection process starts with the ingestion of infective spores by adult honeybees when they are eating contaminated food or when they are cleaning up fecal material from infected bees. The spores germinate in the insect midgut by extruding the polar tube and releasing their sporoplasm into midgut epithelial cells where they generate more spores and leave the body of infected host by defecation. Once in the gut, they invade the ventricular cells causing disease, but the clinical and epidemiological characteristics of the parasitization by either species are different; the infection by N.apis (type A nosemosis) does not usually cause the death of the colonies and is characterized by dysentery, general weakening of the adults, locomotion impairment and crawling (OIE, 2014). These symptoms are not present in $N$. ceranae infections (type $C$ nosemosis) (Higes et al., 2010), which produce alterations in the temporal polyethism, foraging activity and life span of infected bees (Goblirsch et al., 2013; Dussaubat et al., 2013; Alaux et al., 2014). A large-scale depopulation phenomenon, named colony collapse disorder (CCD), has been reported in the United States of America (USA) (Chen et al., 2008) and Europe (Topolska, Gajda \& Hartwig, 2008). Nosema ceranae was suspected to be one of the contributors to this illness, particularly winter colony loses (Klee et al., 2007). However, although some studies implicated

*email: ovidiu.mederle@gmail.com 
N.ceranae infection in the colony collapse of bees in the Mediterranean, particularly in Spain (Higes et al., 2008; Martín-Hernández et al., 2007), their relationship is still an open question. Probably, the delay to detect the first natural infections of $A$. mellifera colonies by $N$. ceranae (Higes et al., 2006; Huang et al., 2007) are associated with the use of 3 light microscopy as a routine diagnostic tool for the detection of Nosema-like spores. Since both species have spores with similar size, an incorrectresultcan easily occur only by using this methodology. Instead, N. ceranae could be clearly separated from its congener $N$. apis based on $16 S$ small subunit (SSU) rRNA gene sequences and ultrastructural features (Fries et al., 1996). Several PCR based molecular techniques for the diagnosis and identification of $N$. apis and $N$. ceranae, such as conventional or duplex PCR, PCR-RFLP, qPCR, multiplex PCR (Higes etal., 2006; Klee etal., 2007; Martin-Hernandez et al., 2007; Chen et al., 2008; Fries et al., 2013) have been described. During the last decade, the arising of molecular techniques capable of distinguish Nosema spp. has led to an increased and even surprising high detection of $N$. ceranae in worldwide $A$. mellifera populations. Furthermore, it was even found to be the predominant Nosema species in many regions of the globe. Several of the major studies reported worldwide on Nosema spp. honeybee infection are summarized in table 1 . These epidemiological evidences point towards the hypothesis that $N$. ceranae has been replacing $N$. apis in the honey bee populations throughout the world (Klee et al., 2007; Chen et al., 2008; Williams et al., 2008; Invernizzi et al., 2009; Chen and Huang, 2010; Yoshiyama and Kimura, 2011; Copley et al., 2012) In Romania, a country in southeastern Europe located on the Balkans Peninsula, N. apis (F. Begnescu) and N. ceranae (I.D.S.A. Bucharest) were described for the first time in 1934 and 2008, respectively. Based on few scientific data presented in workshops and/or national periodics, is thought that $A$. mellifera nosemosis by these two microsporidian species, is a frequently spread infection in this country (Agripina et al., 2017). However, to date there is a lack of publications on this subject in international peer-reviewed journals.

The aims of the present study were to survey the occurrence and identification of Nosema spp. in A. mellifera honeybee colonies from apiaries located in Arad, CarasSeverin and Timis Counties, Romania.

\section{Experimental part}

Materials and Methods

Bee sampling collection

Adult bee samples were collected during 2015 by beekeepers and apiary inspectors in Arad, Caras-Severin and Timis, Counties localized in Southwestern region of Romania, near the border with Hungary, and/or Serbia. Submitters were asked to collect bees from the top lids of bee hives or from around the outside of the brood nest. Most bee samples were collected during the latter part of winter and early spring. All the bee samples were stored in $70 \%(\mathrm{v} / \mathrm{v})$ ethanol at room temperature prior to testing.

\section{Microscopic analysis}

Diagnosis of Nosema spp. infections was performed by light microscopy examination at 400x magnification, of homogenized adult worker honeybees abdomens according to the Manual of Standards for Diagnostics and Vaccines published by the Office International des Epizooties (OIE), the World Organization for Animal Health (OIE, 2013). A total of 690 adult worker honeybees were examined for the presence of Nosema spores.
Spore counting was estimated in some randomly selected positive samples $(n=60)$ by hemocytometer (Fries et al., 2013). Infection levels were classified as low $(<5.0$ million spores per bee), medium $(P \geq 5.0$ $<10.0$ million spores per bee), and high ( $P \geq 10.0$ million spores per bee) according to Yücel and Gogaroglu (2005). As morphological characteristics of $N$. ceranae and $N$. apis spores are very similar and can hardly be distinguished by light microscopy, all samples were also screened by PCR assay based on 16S rRNA-gene-targeted primers, and DNA sequencing to distinguish these two species. Bee homogenates were filtered to remove coarse bee parts and the obtained suspensions were stored at $20^{\circ} \mathrm{C}$ until used for DNA extraction.

\section{Molecular analysis}

Genomic DNA was extracted from the bee homogenates suspensions, using the Fast DNA SPIN kit for soil (Lobo et al., 2006a). A nested PCR protocol, previously described (Lobo et al., 2006b) was used to amplify a fragment of the 165 region of the rRNA gene of Nosema group. The DNA extracted from the homogenates was analyzed at least three times by PCR. The products obtained were analyzed by $1.5 \%$ agarose gel electrophoresis and ethidium bromide staining.

The secondary PCR products were purified using a J etquick kit (Genomed, Lohne, Germany) and sequenced in both directions. The accuracy of the nucleotide sequence was confirmed by sequencing three separate PCR products from the same homogenate. The sequences obtained were analyzed together with the reference sequences from the GenBank database using the BLASTN (www.ncbi. nlm.nih.gov) (Altschul et al., 1997 in papini 2017).and ClustalX (ftp://ftp-igbmc.u-strasbg.fr/pub/ClustalX/) programs.

\section{Results and discussions}

Six hundred and ninety adult bee samples obtained from 37 apiaries from three geographical regions in Romania were submitted for examination of Nosema spp. spores, by light microscopy. Nosema spores appear as oval corpuscles with a size of $2.5-3.0 \mu \mathrm{m}$ in width and $4.3-5.0 \mu \mathrm{m}$ in length $(n=60)$, refractory and with highlighted sporal membrane (fig. 1).

The spore counts by light microscopy indicate the average of $5.5 \times 10^{6}$ spores/bee, without distinction between Nosema spp. species. One hundred and fifty-two

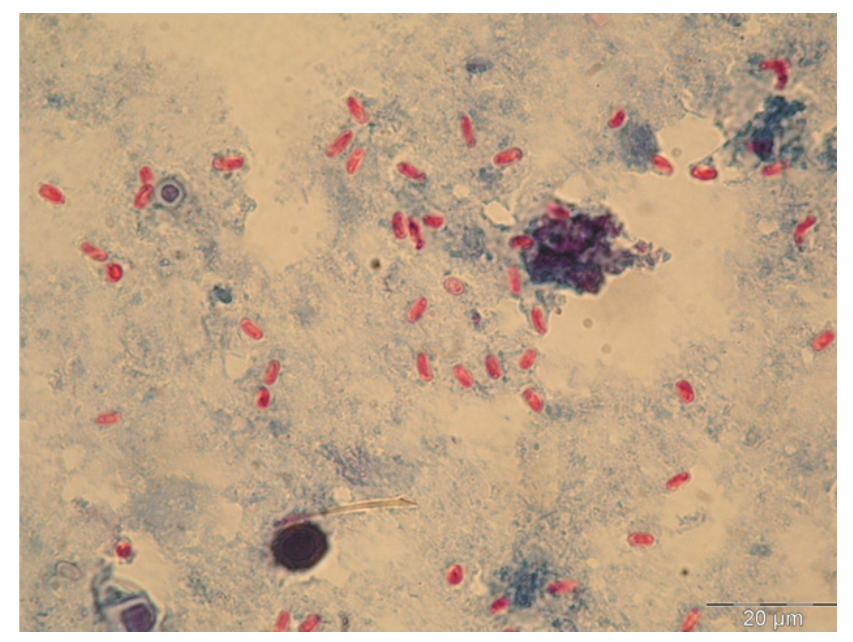

Fig. 1. Light micrograph showing the appearance of Nosema ceranae free spores in smears stained by the Gram-chromotrope method. Magnification $=x 1000$; scale bar $=20 \mu \mathrm{m}$. 
out of 292 (52\%) samples of bees collected from 16 apiaries located in Arad County, 178 out of 323 (55\%) samples of bees collected from 13 apiaries of Timis County and 50 out of $75(66 \%)$ samples of bees collected from eight apiaries in Caras-Severin County were diagnosed with nosemosis, by light microscopy. By PCR, $N$. ceranae was the only Nosema species identified in samples from the three counties. Additionally, selected PCR products from the $N$. ceranae assays were also sequenced and this species was confirmed as the one present in our samples using reference sequences deposited in GenBank. The sequences obtained from the Nosema-infested Romanian honeybees were $100 \%$ identical with the $N$. ceranae sequence, and $92 \%$ like $N$. apis from GenBank database.

Prevalence data reported worldwide for $N$. apis and $N$. ceranae showed that the latter one became the main species in the global $A$. mellifera honey bee populations and it was suggested that $N$. ceranae has replaced or is about to replace its congener globally (Chen et al., 2012; Martin-Hernandez et al., 2012). In the European honeybee $N$. ceranae was first detected in Spain (2006), and this microsporidian has been pointed as the main cause of large-scale colony losses. In Europe, a South to North gradient was observed with $N$. ceranae being dominant in Southern European countries (such as Italy and Greece)whileN.apis was still dominant in some countries from the Northern/Western part of Europe (Ireland, Sweden, Norway, and Germany) (table 1) (Klee et al., 2007). This difference may be a consequence of distinct influence of climatic factors in N. ceranae spread and assertiveness (Fenoy et al., 2009; Martin-Hernandez et al., 2009; Gisder et al., 2010; Chen et al., 2012; Natsopoulou et al., 2015). These data add strong evidence for an advantage of $N$. ceranae over $N$. apis in warmer climates. On the other hand, the cold-sensitivity of $N$. ceranae spores might slow down the replacement process in colder climates (Gisder et al., 2010). The precise momentum in time and the transmission pathway of $N$. ceranae from $A$. cerana to $A$. mellifera are not known. It is hypothesized that throughout the last decades, the rapid, long-distance dissemination of $N$. ceranae is possible due to the transport of infected honey bees and/or by the increased mobility of people, goods and livestock.

Romania is a country included in the Balkans region, and is one of the most important honey producers from Europe and has many melliferous zones of acacia, lime and sun flower plantations all over the country. In 2008, there were registered more than eight hundred thousand bee colonies of $A$. mellifera. During the last two years, an increase in infection by microsporidian parasites in honey bees has been detected in different regions of Romania, while apparently healthy and strong colonies become weak and finally die. In 2007-2008 the number of Nosema outbreaks increased, compared with 2004-2006. The presence of $N$. ceranae was confirmed in Romania (2008) using molecular biology techniques in samples that were first analyzed by microscopy methods (Chioveanu $\mathrm{G}$ et al., unpublished). Until now, information regarding the status on $A$. mellifera honey bee infection by Nosema spp. in this country has not been published. The present study has demonstrated that in Romania Nosema spp. infects bees in the three Western Country Counties of Arad, frequency of $55.1 \%$ of Nosema infection was observed in the regions analyzed (table 1). In addition, $N$. ceranae, was the only species detected by PCR and DNA sequencing. An unpublished study (Chioveanu $G$ etal., unpublished) reports $45.8 \%(60 / 131)$ of Nosema infection based on light microscopy, in bee samples collected from several
Counties (including Arad County) of Romania (March 2007September 2008). In that study, N. ceranae was the only species detected by PCR-RFLP, as it was observed in the present study.

Some data on nosemosis prevalence in bee colonies from Romania bordering countries, and others from Balkan Peninsula are available (table 1). However, comparative study of prevalence rates should be treated with caution, as frequently the results reported cannot be compared because studies used distinct methodologies in the diagnosis of nosemosis that could bias the results and conclusions. For instance, between 2008 and 2012, Stevanovic et al. (2013) found a higher prevalence (73$98 \%$ ) of $N$. ceranae by PCR-RFLP combined technique, in about 200 Serbian $A$. mellifera honey bee colonies (Stevanovic et al., 2011, 2013) (table 1), then the prevalence obtained in our study. A recent retrospective study (2007 to 2015) demonstrated that $N$. ceranae was ubiquitous in that country. An overall frequency of $95.7 \%$ (table 1),ranging annually from $83.3 \%$ to $100 \%$ occurred, according the 57 locations and season of the year monitored (Stevanovic et al., 2016). This microsporidian species has been present in Serbia since at least 2000 and is not considered anymore as an emergent pathogen in this region. Due to the absence of any molecular data there is no confirmation that $N$. ceranae has displaced $N$. apis within Serbian honey bees (Stevanovic et al., 2011). This is in contrast to honey bee microsporidia populations from other regions of Europe where both species have been described, usually with predominance of $N$. ceranae over N. apis (Klee et al., 2007; MartínHernandez et al.,2007) or less frequently predominance of $N$. apis over N. ceranae (Forsgren and Fries, 2013). In Hungary, from 38 Nosema-infested bee samples (20062007) from geographically distant bee colonies representing all regions of the country, only one sample contained N. apis, and in the remaining samples N. ceranae was detected, which also indicates the dominance of $N$. ceranae in Hungarian apiaries. More recently, Shumkova et al., 2018, reported $A$. mellifera infection by $N$. ceranae with an overall prevalence rate of $52.8 \%(13.9-77.2 \%)$ in three different regions of Bulgaria. As observed in the present study and in Serbia apiaries, $N$. apis species was not detected in Bulgaria. In the Northern border of Romania, a study carried on Ukraine (Odnosum HV, 2017) reported the occurrence of $38.9,25.5$ and $35.6 \%$ of $N$. ceranae, $N$. apisand co-infection by both species, respectively. These data add evidence to the predominance of $N$. ceranae in all these monitored countries from the Balkans region and Eastern Europe.

The occurrence of a high prevalence of Nosema infection observed in all the apiaries studied, even without the presence of clinical symptomatology, may also constitute an increased risk for the honeybee colonies of being affected concomitantly by other pathogens. It is known, that the infection of honeybees with one parasite may affect their susceptibility to infection by another parasite, either by increasing or decreasing host susceptibility to co-infection (reviewed in Evans and Schwarz [2011] and Schwarz et al. [2015b]). Thus, it is important to monitor these apiaries for other common bee pathogens.

Whilst $N$. apis infection seems to cause a fast acting, shortduration syndrome, this has not been the case for $N$. ceranae, which instead has been observed in association with non-specific symptoms, resembling colony collapse disorder (CCD), such as a gradual depopulation, higher autumn/winter mortality in colonies or low honey production (Fries et al., 2006). It has also 
recently been shown that $N$. ceranae does not display the seasonality that is seen with N. apis (Giersch et al., 2009). When the virulence of $N$. apisand $N$. ceranaewas evaluated in experimentally inoculated $A$. mellifera assays the latter seemed to induce significantly higher mortality in comparison to N. apis (Higes et al., 2007; Paxton et al., 2007). Furthermore, in several European countries some studies describe $N$. ceranae as the more virulent species and thus may have a competitive advantage in comparison to N. apis (Klee et al., 2007; Paxton et al., 2007; Forsgren \& Fries, 2010). Dissimilar data, reported mainly in the USA, do not support these observations (Huang et al., 2015; Milbrath et al., 2015). Accordingly, to their results, it is suggested that the North American honeybees may be less susceptible to $N$. ceranae infections than European bees or that the US isolates of the pathogen are less infective and less virulent than European isolates. (Shumkova et al. (2018). Based on the available information, the effect of $N$. ceranae at the colony level and its role in colony losses diverge in different geographic regions. This difference is attributed to the presence of multiple factors, such as the genetic background of the pathogen and the host, climatic factors or other environmental conditions, and colony management.

During the present study, the health of honeybee colonies from the apiaries monitored for Nosema spp. infection was evaluated. About $54 \%$ of the total (52\%) samples diagnosed with nosemosis from Arad County (region from wester Romania bordering with Southeast Hungary) were collected from asymptomatic bee colonies, most of which were observed during the warm season. Thirty percent of the samples infected with Nosema came from dead bee colonies in the latter half of winter. In most cases, over $90 \%$ of colonies of bees which began wintering as powerful colonies, died. All the bees were fallen from the honeycombs in which some of the stuffed nourishment can be seen. Some of the honey reserves were inappropriate, uncooked, fermented and moldy, which made it possible to trigger acute nosemosis manifested by diarrhea and mortality. Atall these bee colonies, Nosema spores were identified at very high levels. At the end of winter and early spring, a small number of colonies (9\%) presented CCD.

These bee colonies were introduced atstrong wintering, according to the beekeepers' declarations.

In this study, the depopulated and missing colonies were observed in spring and autumn. In most cases, the colonies of dead bees diagnosed with nosemosis were observed in the second month of the year and less in the third month. In one situation, cases of dead bee colonies of nosemosis were diagnosed during autumn. The death of bees in the second half of winter is often caused by nosemosis (Higes et al., 2013; Chen and Huang, 2010; Fries I, 2010, Paxton RJ , 2010), which can also be observed in the present study. It can be noticed that mortality can be associated with the diagnosis of nosemosis, butnot always clinically manifested, since only a small part of the dead colonies also presented symptoms of diarrhea. These observations can point out to the diagnosis of C-type nosemosis (infection by N. ceranae) in which the evolution is acute and the colony of bees dies before the visible symptoms of the disease arise [Higes M. et al. 2010, CoxFoster, D.L. et al., 2007, Fries, I., 2007]. Bee colonies diagnosed with nosemosis associated with diarrhea symptoms were only recorded in the second half of the winter, January to February. During this period, Nosema infection may evolve into clinical manifestations that are probably linked to a set of factors that potentiate the intensity of the infection: the growth of the juvenile, the increase of the temperature in the hive, the intensification of the activity in the wintering pad, the increase of the consumption of energy-protein reserves, the effects of fecal accumulation inside the hive associated with the almost exclusive indoor activity of bees. Concerning Timis County (region below Arad County and bordering with Northeast Servia), about $69 \%$ of Nosema-positive samples determined for this county (55\%) in the present study were originated from asymptomatic bee colonies. Most of dead bee's colonies diagnosed with Nosema infection were also found in the second half of winter and early spring, February to March. However, on these bees colonies, were detected symptoms of diarrhea concomitantly with very high levels of Nosema infection. The colonies of dead bees diagnosed with Nosema infection were also found during the autumn, but they did not show visible symptoms of disease. The colonies infected with Nosema can be found throughout the year and have an importantepidemiological role. They maintain the risk of a clinical episode in the apiary, especially during winter. Infected bee colonies are dangerous not only for the apiary, but also represent a serious risk of contamination to other apiaries and can spread over hundreds of kilometers by practicing the pastoral. Bees infected with Nosema have less longevity than healthy bees, which explain depopulation in bee's colonies with nosemosis. In massive winter depopulation, Nosema has an important role in reducing the longevity of working bees due to lesions and energy stress, and due to the reduction of the queen eggs (Mayack $\&$ Naug, 2009). In Caras-Severin County (region Southwest Romania and bordering Servia), $38 \%$ of bee samples with nosemosis monitored in this area $(66 \%)$ come from colonies of depopulated bees. About $28 \%$ of the samples diagnosed with Nosema infection were collected from dead bee colonies in the latter half of winter. While $20 \%$ of bee colonies with Nosema infection do not display symptoms, about $14 \%$ of the colonies presented diarrhea. During the study, in Cara--Severin County, colonies of bees with CCD syndrome was not identified. Overall, health evaluation of bee colonies from the apiaries of the three counties monitored in the present study highlighted the presence of a high number of bee colonies without symptomatology but carriers of Nosema spp. And a lesser number of bee colonies with manifested disease. Also, it was observed bee colonies with depopulation, morbidity and positive testing for Nosema spp. In the present study, most of the dead bees infected with Nosema spp. were observed in the second/latter half of the winter, as reported for $N$. ceranae by other authors (Chen and Huang, 2010; Paxton RJ, 2010; OEI, 2014).

Some studies in Romania bordering countries and other countries from Balkan Peninsula present several results like those reported in this study, namely the predominance of N. ceranae over N. apis (table I), and some of the typical pattern of infection associated with $N$. ceranae nosemosis (Chen and Huang, 2010; Fries I, 2010; Stevanovic et al., 2013; Odnosum HV, 2017). Based on the literature, N. ceranae infections have not reported typical signs of Nosema infection. For example, dysentery and crawling bees may well be absent, and manytimes infected bees are asymptomatic (Chen and Huang, 2010; Fries I, 2010, Paxton RJ, 2010; Higes et al., 2013). Some discrepancies in data colony-level pathology, characteristics and outcome of $N$. ceranae infection, observed in the three Romanian counties monitored, have also been described in other studies (Alaux et al. 2010; Fries 2010; Higes et al. 2010a; Paxton RJ , 2010; Gisder et 
Table 1

REVIEW OF THE MAIN STUDIES ON DETECTION AND DISTRIBUTION OF NOSEMA SPP. INFECTION IN HONEY BEE POPULATIONS WORLDWIDE REPORTED IN SCIENTIFIC PUBLICATIONS.

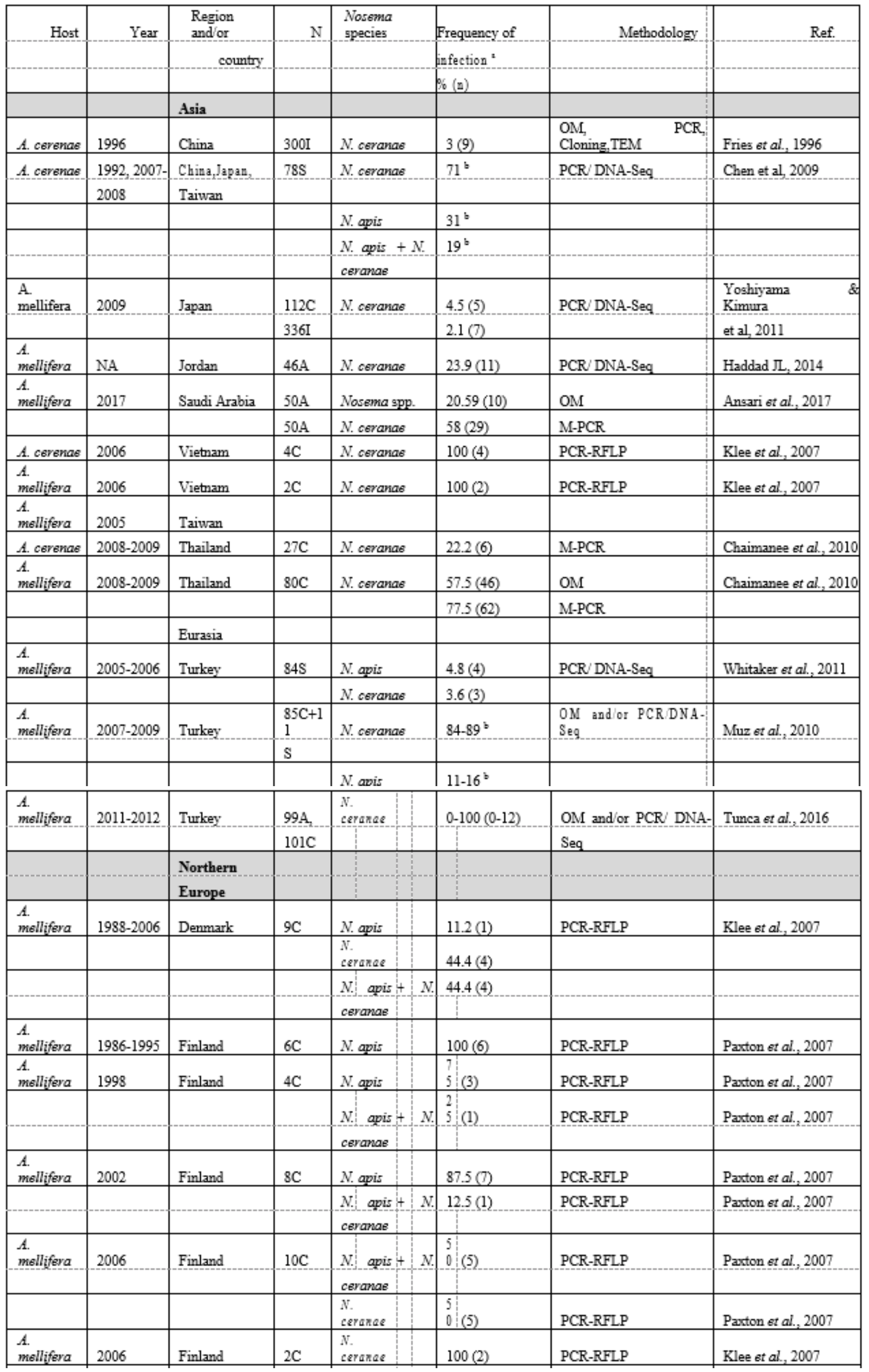




\begin{tabular}{|c|c|c|c|c|c|c|c|c|c|}
\hline A. & $\begin{array}{l}1998, \\
2003,\end{array}$ & Sweden & $5 \mathrm{C}$ & N. apis & & 100 & $(5)$ & PCR-RFLP & Klee et al 2007 \\
\hline & 2005 & & & & & & & & \\
\hline $\begin{array}{l}\text { A. } \\
\text { mellifera }\end{array}$ & 2006 & Sweden & $2 \mathrm{C}$ & N. apis & & $\begin{array}{l:l}5 & \\
0 & (\end{array}$ & (1) & PCR-RFLP & Klee et al, 2007 \\
\hline & & & & N: apis + & $N$ & $\begin{array}{l:l}5 \\
0\end{array}$ & (1) & & \\
\hline & & & & ceranae & & & & & \\
\hline A. & NA & Sweden & NA & $\begin{array}{l}\text { Nosema } \\
\text { spp. }\end{array}$ & & 319 & & $\mathrm{OM}$ & Fries and Forsgren, \\
\hline & & & & & & & & & 2008 (in Fries, 2010) \\
\hline & & & $319 \mathrm{~S}$ & N. apis & & & $02(83)$ & PCR & \\
\hline & & & & N. apis + & $N$ & & $3(17)$ & & \\
\hline & & & & ceranae & & & & & \\
\hline A. & $2011-2014$ & Lithuania & $347 \mathrm{C}$ & Nosema & & & (153) & PCR/DNA-Seq & Blažytè-Cereškienè $e t$ \\
\hline & & colonies & & & & & & & al. 2016 \\
\hline & & & $153 \mathrm{C}$ & $\begin{array}{l}\text { N. } \\
\text { ceranae }\end{array}$ & & $\begin{array}{l}38 . \\
6 \\
\end{array}$ & (59) & & \\
\hline & & & & N. apis & & $\begin{array}{l}37 . \\
2 \\
\end{array}$ & $(57)$ & & \\
\hline & & & & $N$ apis 4 & $N$. & $\begin{array}{l}24 \\
2\end{array}$ & (37) & & \\
\hline & & & & ceranae & & & & & \\
\hline & & $\begin{array}{l}\text { Eastern } \\
\text { Europe }\end{array}$ & & & & & & & \\
\hline A. & $2014-2016$ & Uloraine & $784 \mathrm{~S}$ & N. apis & & $\begin{array}{l}25 . \\
5 \\
-\end{array}$ & $(200)$ & $\mathrm{OM}$ and/or PCR DNA- & $\begin{array}{l}\text { Odnosum } \\
2017\end{array}$ \\
\hline & & & & & & & & Seq & \\
\hline & & & & $\begin{array}{l}\text { N. } \\
\text { ceranae }\end{array}$ & & $\begin{array}{l}38 . \\
9\end{array}$ & (305) & & \\
\hline & & & & $N$ apis + & $N$ & $\begin{array}{l}35 . \\
6\end{array}$ & $(279)$ & & \\
\hline & & & & ceranae & & & & & \\
\hline & & $\begin{array}{l}\text { Central } \\
\text { Europe }\end{array}$ & & & & & & & \\
\hline A. & 2003,2005 & Germany & $69 \mathrm{~S}$ & $\begin{array}{l}\text { N. } \\
\text { ceranas }\end{array}$ & & $\begin{array}{l}78 . \\
3 \\
\end{array}$ & (54) & M-PCR & Martin-Hernandez $e t$ \\
\hline & 2006 & & & & & & & & al. 2007 \\
\hline & & & & N. apis & & 7.2 & (5) & & \\
\hline & & & & $N$ apis t & $N$ & 2.9 & (2) & & \\
\hline & & & & ceranae & & & & & \\
\hline $\begin{array}{l}\text { A. } \\
\text { mellifera }\end{array}$ & 2006 & Germany & $34 \mathrm{C}$ & $\begin{array}{l}\text { N. } \\
\text { cerance }\end{array}$ & & $\begin{array}{l}50 . \\
0 \\
\end{array}$ & (17) & PCR-RFLP & Klee et al, 2007 \\
\hline & & & & N. apis & & $\begin{array}{l}23 . \\
5\end{array}$ & (8) & & \\
\hline & & & & $N$ apis : & $N$ & $\begin{array}{l}26 . \\
5\end{array}$ & (9) & & \\
\hline & & & & ceranae & & & & & \\
\hline A. & $2005-2016$ & Germany & $5600 \mathrm{C}$ & N. apis & & & $-18.7(4-43)^{6}$ & OM and/or PCR-RFLP & Gisder ot al. 2017 \\
\hline & & & & $\begin{array}{l}\text { N. } \\
\text { cerance } \\
\end{array}$ & & & $-14.9(3-34)^{\circ}$ & & \\
\hline & & & & N. apis + & $N$ & & $-10.1(0-21)^{=}$ & & \\
\hline & & & & ceranae & & & & & \\
\hline $\begin{array}{l}\text { A. } \\
\text { mellifera }\end{array}$ & 1994 & Hungary & $1 \mathrm{C}$ & N. apis & & 100 & (1) & PCR-RFLP & Klee et al, 2007 \\
\hline $\begin{array}{l}\text { A. } \\
\text { mellifera }\end{array}$ & 2006-2007 & Hungary & $38 \mathrm{~S}$ & $\begin{array}{l}\text { N. } \\
\text { ceranae }\end{array}$ & & $\begin{array}{l}97 . \\
4 \\
\end{array}$ & $(37)$ & PCR-RFLP & $\begin{array}{l}\text { Tapaszti } \text { ot } \\
2009\end{array}$ \\
\hline & & & & N. apis & & 2.6 & (1) & & \\
\hline $\begin{array}{l}\text { A. } \\
\text { mellifera }\end{array}$ & 2017 & Hungary & $225 \mathrm{C}$ & $\begin{array}{l}\text { Nosema } \\
\text { spp. }\end{array}$ & & $\begin{array}{l}47 . \\
8\end{array}$ & (112) & $\mathrm{OM}$ & $\begin{array}{l}\text { Agripina ot al, } \\
2017\end{array}$ \\
\hline A. & 2006 & Switzerland & $36 \mathrm{~S}$ & $\begin{array}{l}\text { N. } \\
\text { ceranae }\end{array}$ & & $\begin{array}{l}63 . \\
9\end{array}$ & (23) & M-PCR & Martin-Hernandez et \\
\hline & & & & & & & & & al, 2007 \\
\hline & & & & N. apis & & 2.8 & (1) & & \\
\hline $\begin{array}{l}\text { A. } \\
\text { mellifera }\end{array}$ & 2011 & Switzerland & $408 \mathrm{I}$ & $\begin{array}{l}\text { N. } \\
\text { ceranae }\end{array}$ & & $\begin{array}{l}23 . \\
5\end{array}$ & (96) & PCR/DNA-Seq & Tritscheler et al, 2016 \\
\hline & & Western & & & & & & & \\
\hline & & & & & & & & & \\
\hline & & Europe & & & & & & & \\
\hline
\end{tabular}




\begin{tabular}{|c|c|c|c|c|c|c|c|}
\hline $\begin{array}{l}\text { A. } \\
\text { mellifera }\end{array}$ & $2002-2005$ & $\begin{array}{l}\text { Franc } \\
\text { le }\end{array}$ & $61 \mathrm{~S}$ & $\begin{array}{l}\text { N. } \\
\text { ceranae }\end{array}$ & $59(36)$ & PCR/DNA-Seq & $\begin{array}{l}\begin{array}{l}\text { Chauzat et al. } \\
2007\end{array} \\
\end{array}$ \\
\hline & & & & N. apis & $1.6(1)$ & & \\
\hline & & & & $N$ apis $+N$ & $6.6(4)$ & & \\
\hline & & & & ceranae & & & \\
\hline \multirow[t]{4}{*}{$\begin{array}{l}\text { A. } \\
\text { mellifera }\end{array}$} & 2006 & Franc & $36 \mathrm{~S}$ & $\begin{array}{l}\text { N. } \\
\text { ceranae }\end{array}$ & $75(27)$ & M-PCR & Martin-Hernandez et \\
\hline & & & & & & & al. 2007 \\
\hline & & & & $N$ apis $N$. & $\begin{array}{l:l}16 & \\
7 & (6) \\
\end{array}$ & & \\
\hline & & & & ceranae & & & \\
\hline \multirow[t]{5}{*}{$\begin{array}{l}\text { A. } \\
\text { mellifera }\end{array}$} & 2005 & $\begin{array}{l}\text { Irelan } \\
\text { d }\end{array}$ & $1 \mathrm{C}$ & $N$ apis & $100(1)$ & PCR-RFLP & Klee et al., 2007 \\
\hline & 2007-NA & England & $309 \mathrm{~S}$ & N. apis & $10(31)$ & $\mathrm{RT} \mathrm{qPCR}$ & Budge et al., 2008 \\
\hline & & & & $\begin{array}{l}\text { N. } \\
\text { ceranae }\end{array}$ & $4.5(14)$ & & \\
\hline & & & & $\begin{array}{l:l:l}N & & \\
& \text { apis } & + \\
\end{array}$ & \begin{tabular}{l:l}
1 & \\
$(3)$ & \\
\hdashline
\end{tabular} & & \\
\hline & & & & ceranae & & & \\
\hline \multirow[t]{5}{*}{$\begin{array}{l}\text { A. } \\
\text { mellifera }\end{array}$} & $\begin{array}{l}2001 \\
2005\end{array}$ & UK Norther & $3 \mathrm{C}$ & N. apis & $100(3)$ & PCR-RFLP & Klee et al 2007 \\
\hline & 2006 & Ireland) & & & & & \\
\hline & & Southeastern & & & & & \\
\hline & & & & & & & \\
\hline & & Europe & & & & & \\
\hline \multirow[t]{2}{*}{ A. } & $2006-2009$ & FYROM & $37 \mathrm{~S}$ & $\begin{array}{l}\text { N. } \\
\text { ceranae }\end{array}$ & $\begin{array}{l:l}94 . & \\
6 & (35) \\
\end{array}$ & OM, PCR and/or PCR- & Stevanovic et al. 2011 \\
\hline & & & & & & RFLP & \\
\hline \multirow[t]{2}{*}{ A. } & $2006-2009$ & \begin{tabular}{l|l}
$B o s n i$ & \\
$a$ & and
\end{tabular} & $45 \mathrm{~S}$ & $\begin{array}{l}\text { N. } \\
\text { cerange }\end{array}$ & $\begin{array}{l:l}84 . & \\
4 & (38)\end{array}$ & OM PCR and/or PCR- & Stevanovic et al, 2011 \\
\hline & & Herzegovina & & : & & RFLP & \\
\hline \multirow[t]{4}{*}{ A. } & 2017 & Bulgaria & $108 \mathrm{~S}_{i}$ & $\begin{array}{l}\text { N. } \\
\text { cerange }\end{array}$ & $\begin{array}{l:l}52 . & \\
8 & (57)^{d} \\
\end{array}$ & PCR/DNA-Seq & Shumkova et al. 2018 \\
\hline & & 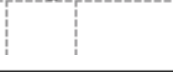 & $36 \mathrm{~S}$ & -2 & $\begin{array}{l:l}13 . & \\
9 & (5)\end{array}$ & & \\
\hline & & & $28 \mathrm{~S}$ & & $\begin{array}{l:l}64 & \\
3 & (18)\end{array}$ & & \\
\hline & & & $44 \mathrm{~S}$ & & \begin{tabular}{l|l}
77 & \\
2 & $(34)$ \\
\end{tabular} & & \\
\hline \multirow[t]{2}{*}{ A. } & $2006-2009$ & \multirow[t]{2}{*}{ Munlenezzus } & 283 & N. cercurues & $\begin{array}{l:l}78 & \\
6 & (22) \\
\end{array}$ & OM, PCR $\triangle \mathrm{ad} / \mathrm{SCCR}$ & Stevaruvic es ul, 2011 \\
\hline & & & & & & RF_P & \\
\hline $\begin{array}{l}\text { A. } \\
\text { mellifera }\end{array}$ & 2015 & Romania & $690^{\circ}$ & N. ceraras & $\begin{array}{l:l}55 & \\
1 & (380) \\
\end{array}$ & OM, PCR DNA-Seq & In the present study \\
\hline $\begin{array}{l}\text { A. } \\
\text { mellifera }\end{array}$ & 2006 & Serbia & $4 \mathrm{C}$ & N. cerarae & $100(4)$ & PCR-RFLP & Klee et al, 2007 \\
\hline $\begin{array}{l}\text { A. } \\
\text { mellifera }\end{array}$ & $\begin{array}{l}2000-2005 \\
2006-2009 \\
\end{array}$ & Serbia & $215 \mathrm{~s}$ & N. ceraras & \begin{tabular}{l|l}
82 & \\
3 & $(178)$
\end{tabular} & $\begin{array}{l}\text { ON, PCR and } ₫ \text { PCR- } \\
\text { RF_P }\end{array}$ & Steranovic ex al., 2011 \\
\hline & & & & N. apis & $0.5(1)$ & & \\
\hline A. & $20 \cap R-2012$ & Serinia & 2008 & $N_{\text {cermane }}$ & $73.98^{b}$ & OM, PCR and/ $\pi$ PCR- & Ster ancir at al 2n1\} \\
\hline & & & & & & RF_P & \\
\hline $\begin{array}{l}\text { A. } \\
\text { melliferu }\end{array}$ & $2007-2015$ & Serbid & 1620 & N. cercurus & $\begin{array}{l:l}95 & \\
7 & (155) \\
\end{array}$ & PCR aml/u PCR-RILP & Stevaruvic ex ul., 2016 \\
\hline & & Suthern & & & & & \\
\hline & & Europe & & & & & \\
\hline $\begin{array}{l}\text { A. } \\
\text { mellifera }\end{array}$ & $2005-2006$ & Greece & $3 \mathrm{C}$ & N. ceraras & $100(3)$ & PCR-RFLP & Klee et al, 2007 \\
\hline mellifera & $\begin{array}{l}1993,1998, \\
2\end{array}$ & Italy & $6 \mathrm{C}$ & N. ceraras & $50(3)$ & & Ferrogliv ot al. 2012 \\
\hline & 010 & & & & & & \\
\hline & & & & N. apis & $\begin{array}{l:l}16 & \\
7 & (1) \\
\end{array}$ & & \\
\hline & & & & N. apis + 3N & $\begin{array}{l:l}16 & \\
7 & (1) \\
\end{array}$ & & \\
\hline & & & & SRVAMIR & & & \\
\hline $\begin{array}{l}\text { A. } \\
\text { mellifera }\end{array}$ & 1994 & Italy & $1 \mathrm{C}$ & N. apis & $100(1)$ & PCX-RFLP & Klee er al, 2007 \\
\hline $\begin{array}{l}\text { A. } \\
\text { mellifera }\end{array}$ & $2005-2006$ & Italy & $26 \mathrm{C}$ & N. ceraras & $100(26)$ & PCR-RFLP & Klee et al., 2007 \\
\hline A.llifera & $2014-2015$ & Italy & $38 \mathrm{~A}$ & N. cerarae & $\begin{array}{l:l}63 & \\
2 & (24) \\
\end{array}$ & $\mathrm{OM}$ and M-PCR & Parini et al, 2017 \\
\hline
\end{tabular}




\begin{tabular}{|c|c|c|c|c|c|c|c|}
\hline $\begin{array}{l}\text { A. } \\
\text { mellifera }\end{array}$ & $2004-2005$ & Spain & $12 \mathrm{~s}$ & N. apis & $8.3(1)$ & PCR & Higes es al. 2000 \\
\hline & & & & N. cernaras & \begin{tabular}{|l|l|}
91 & \\
7 & (11) \\
\end{tabular} & & \\
\hline $\begin{array}{l}\text { A. } \\
\text { mellifera }\end{array}$ & $2004-2005$ & Spain & $10 \mathrm{C}$ & N. cerarae & $100(10)$ & PCR-RFLP & Klee et al, 2007 \\
\hline $\begin{array}{l}\text { A. } \\
\text { mellifera }\end{array}$ & $2005-2006$ & Spain & $149 \mathrm{~S}$ & N. cerarae. & \begin{tabular}{l|l}
34 & \\
9 & $(52)$
\end{tabular} & M.PCR & Martin-Hemandezet \\
\hline & & & & & & & al. 2007 \\
\hline & & & & N. apis & \begin{tabular}{l|l}
14 & $(21)$ \\
1 &
\end{tabular} & & \\
\hline
\end{tabular}

\begin{tabular}{|c|c|c|c|c|c|c|c|c|c|}
\hline & & & & & $N$ apis + & $N$ & $7.4(11)$ & & \\
\hline & & & & & ceranae & & & & \\
\hline & & North An & merica & & & & & & \\
\hline $\begin{array}{l}\text { A. } \\
\text { mellifera }\end{array}$ & 2008 & Canada & & $169 \mathrm{C}$ & $\begin{array}{l}\text { N. } \\
\text { ceranae }\end{array}$ & & \begin{tabular}{|l|l|}
5 & \\
1 & $(86)$ \\
\end{tabular} & Triplex PCR & Emsen et al., 2016 \\
\hline & & & & & N. apis & & $\begin{array}{l:l}3 & \\
4 & (58) \\
\end{array}$ & & \\
\hline & & & & & N. apis + & $N$ & \begin{tabular}{l|l}
1 & \\
5 & $(25)$ \\
\end{tabular} & & \\
\hline & & & & & ceranae & & 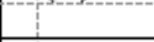 & & \\
\hline $\begin{array}{l}\text { A. } \\
\text { mellifera }\end{array}$ & 2010 & Canada & & $76 \mathrm{C}$ & $\begin{array}{l}\text { N. } \\
\text { ceranae }\end{array}$ & & \begin{tabular}{|l|l|}
4 & \\
1 & $(31)$ \\
\end{tabular} & Triplex PCR & Emsen et al., 2016 \\
\hline & & & & & $N$. apis & & $\begin{array}{l:l}3 & \\
4 & (26) \\
\end{array}$ & & \\
\hline & & & & & \begin{tabular}{l|l} 
& apis \\
\end{tabular} & $N$ & \begin{tabular}{|l|l|}
2 & \\
5 & $(19)$ \\
\end{tabular} & & \\
\hline & & & & & ceranae & & & & \\
\hline $\begin{array}{l}\text { A. } \\
\text { mellifera }\end{array}$ & 2012 & Canada & & $181 \mathrm{C}$ & $\begin{array}{l}\text { N. } \\
\text { ceranae }\end{array}$ & & \begin{tabular}{|l|l|}
9 & \\
1 & $(165)$ \\
\end{tabular} & Triplex PCR & Emsen et al, 2016 \\
\hline & & & & & $N$. apis & & $4(7)$ & & \\
\hline & & & & & Nispis at & $N$ & $5(9)$ & & \\
\hline & & & & & ceranae & & & & \\
\hline A. & $2006-2007$ & Maritime & & $56 \mathrm{C}$ & $\begin{array}{l}\text { Nosema } \\
\text { spp. }\end{array}$ & & $23.2(13)$ & $\mathrm{OM}$ & Williams et al, 2008 \\
\hline & & Provinces & of & & & & & & \\
\hline & & Canada & and & & & & & & \\
\hline & & $\begin{array}{l}\text { Minnesot } \\
\mathrm{a}\end{array}$ & & & & & & & \\
\hline & & & & $8 S=$ & $\begin{array}{l}\text { N. } \\
\text { ceranae }\end{array}$ & & $100(8)$ & PCR & \\
\hline $\begin{array}{l}\text { A. } \\
\text { mellifera }\end{array}$ & $1995-2007$ & USA & & $180 \mathrm{I}$ & $\begin{array}{l}\text { N. } \\
\text { ceranae }\end{array}$ & & $\begin{array}{l:l}1 & \\
6 & (28) \\
\end{array}$ & PCR/DNA-Seq & Chen ot al., 2008 \\
\hline $\begin{array}{l}\text { A. } \\
\text { mellifera }\end{array}$ & 2004 & USA & & $1 \mathrm{C}$ & $\begin{array}{l}\text { N. } \\
\text { ceranae } \\
\end{array}$ & & $100(1)$ & PCR-RFLP & Klee et al., 2007 \\
\hline $\begin{array}{l}\text { A. } \\
\text { mellifera }\end{array}$ & 2009 & USA & & $293 \mathrm{C}$ & $\begin{array}{l}\text { Nosema } \\
\text { spp. }\end{array}$ & & $37.5(110)$ & $\mathrm{OM}$ & Traver \& Fell, 2011 \\
\hline & & & & $293 \mathrm{C}$ & $\begin{array}{l}\text { Nosema } \\
\text { spp. }\end{array}$ & & $69.3(203)^{f}$ & $Q \mathrm{PCR}$ & \\
\hline & & & & $293 \mathrm{C}$ & $\begin{array}{l}\text { N. } \\
\text { ceranae }\end{array}$ & & $34.8(102)^{f}$ & & \\
\hline & & & & & Nitapis t & $N$ & $2.7(8)^{f}$ & & \\
\hline & & & & & ceranae & & & & \\
\hline & & South An & nerica & & & & 7 & & \\
\hline $\begin{array}{l}\text { A. } \\
\text { mellifera }\end{array}$ & 2006 & Brazil & & $3 \mathrm{C}$ & $\begin{array}{l}\text { N. } \\
\text { ceranae }\end{array}$ & & $100(3)$ & PCR-RFLP & Klee et al., 2007 \\
\hline
\end{tabular}

\begin{tabular}{|c|c|c|c|c|c|c|c|c|}
\hline $\begin{array}{l}\text { A. } \\
\text { mellifera }\end{array}$ & $2009-2012$ & Brazil & $637 \mathrm{~S}$ & $\begin{array}{l}\text { Nosema } \\
\text { spp. }\end{array}$ & & \begin{tabular}{l|l}
79 & \\
9 & $(509)$ \\
\end{tabular} & $\mathrm{OM}$ & Teixeira et al., 2013 \\
\hline & & & $509 \mathrm{~S}$ & $\begin{array}{l}N . \\
\text { ceranae }\end{array}$ & & $98.82(503)$ & PCR/ DNA-Seq & \\
\hline & & & & $N$ apis & $N$. & \begin{tabular}{l|l}
0.7 & \\
9 & $(4)$
\end{tabular} & & \\
\hline & & & & ceranae & & & & \\
\hline & & & & N. apis & & \begin{tabular}{l|l}
0.3 & \\
9 & $(2)$ \\
\end{tabular} & & \\
\hline $\begin{array}{l}\text { A. } \\
\text { mellifera }\end{array}$ & $2010-2011$ & Chile & $240 \mathrm{C}$ & $\begin{array}{l}\text { N. } \\
\text { ceranae }\end{array}$ & & $49(117)$ & RT-PCR & Martinez et al., 2012 \\
\hline $\begin{array}{l}\text { A. } \\
\text { mellifera }\end{array}$ & $1995-1996$ & Mexico & $10 \mathrm{C}$ & $\begin{array}{l}\text { N. } \\
\text { ceranee }\end{array}$ & & $100(10)$ & PCR & Guerrero-Molina et al. \\
\hline & & & & & & & & 2016 \\
\hline $\begin{array}{l}\text { A. } \\
\text { mellifera }\end{array}$ & $\sim 1990$ & Uruguay & $29 \mathrm{~S}$ & $\begin{array}{l}\text { N. } \\
\text { cergnae }\end{array}$ & & $100(29)$ & $\begin{array}{l}\text { PCR-RFLP and DNA- } \\
\text { Seq }\end{array}$ & Invernizzi et al, 2009 \\
\hline & 2004,2007 & samples & & & & & & \\
\hline & 2008 & & & & & & & \\
\hline
\end{tabular}




\begin{tabular}{|c|c|c|c|c|c|c|c|c|c|}
\hline & & Africa & & & & & & & \\
\hline \multirow[t]{5}{*}{$\begin{array}{l}\text { A. } \\
\text { mellifera }\end{array}$} & $2014-2015$ & Uganda & $380 \mathrm{C}$ & $\begin{array}{l}N . \\
\text { ceranae }\end{array}$ & & \multicolumn{2}{|c|}{$1.6(6)$} & OM and/or RT PCR & Chemurot et al., 2017 \\
\hline & & & & $N$ apis & & \multicolumn{2}{|c|}{$1.6(6)$} & & \\
\hline & & & & Nosema & & $\begin{array}{l}27 \\
9\end{array}$ & (106) & & \\
\hline & & & & \multicolumn{2}{|c|}{ netmanni $\mathrm{n}$. sp. } & & & & \\
\hline & & Oceania & & & & & & & \\
\hline \multirow[t]{4}{*}{$\begin{array}{l}\text { A. } \\
\text { mellifera }\end{array}$} & $2007-2008$ & Australia & $307 \mathrm{I}$ & N. apis & & $\begin{array}{l}45 \\
6 \\
\end{array}$ & $(140)$ & $\mathrm{OM}$ and/or PCR-RFLP & Giersh et al., 2009 \\
\hline & & & & $\begin{array}{l}N . \\
\text { ceranae }\end{array}$ & & $\begin{array}{l}15 \\
3\end{array}$ & (47) & & \\
\hline & & & & $N$ apis & $N$ & \multicolumn{2}{|c|}{$0.7(2)$} & & \\
\hline & & & & ceranae & & & & & \\
\hline \multirow[t]{4}{*}{$\begin{array}{l}\text { A. } \\
\text { mellifera }\end{array}$} & 2006 & New Zeland & $115 \mathrm{C}$ & $\begin{array}{l}N . \\
\text { ceranae }\end{array}$ & & $\begin{array}{l}66 . \\
1\end{array}$ & (76) & PCR-RFLP & Klee et al, 2007 \\
\hline & & & & N. apis & & $\begin{array}{l}21 \\
7\end{array}$ & (25) & & \\
\hline & & & & \multicolumn{2}{|c|}{$N$ apis $+N$} & 12.2 & $2(14)$ & & \\
\hline & & & & ceranae & & & & & \\
\hline
\end{tabular}

al. 2010). Thus, further investigations on N. ceranae seasonality patterns and impact on individual/colony health are still necessary.

Romania has a climate that is temperate and continental. However, there are some regional differences. For instance, in the western parts, such as the region of Romanian Banat, where the three counties analyzed in this study are located, the climate is milder and has Mediterranean influences. Among other factors, the climatic conditions of the studied area may justify some of the similarities of prevalence, predominance and clinical impact of $N$. ceranae in colonies of $A$. mellifera bees that are characteristic of nosemosis reported in Mediterranean countries (Fries I, 2010; Gisder et al., 2017).

Another potential factor involved in the N. ceranaeimpact on individual and/or colony level is the genetic background of the host. Apis mellifera subspecies differentiation strongly correlates with the distinct temperature zones of Romania. Apis mellifera carnica is more abundant in regions with the mean average temperature below $9{ }^{\circ} \mathrm{C}$, whereas $A$. $m$. macedonica honeybees are more frequent in regions with mean temperatures above $9^{\circ} \mathrm{C}$. Coroian et al. (2014) reported A. m. macedonica as the more frequent endemic subspecies compared with $A$. m. carnica, in these southern regions of Romania. However, these two subspecies are reported to share the same habitat at Arad and Timis Counties. Currently, it is suggested the importance of the genetic background of bee colonies in the susceptibility process to Nosema spp. infection (Invernizzi et al., 2009). For instance, some specific $A$. mellifera subspecies seem to be less susceptible to $N$. ceranae infection and thus could explain some differences on prevalence and effect of $N$. ceranae infection observed in distinct subspecies of $A$. mellifera bee colonies (Shunkova et al., 2018). No information about the impact of Nosema spp., in the different endemic $A$. mellifera subspecies colonies are available for Romania. Thus, epidemiological studies evaluating host-parasite interactions throughout all Romanian regions are still necessary.

Molecular methods are necessary to distinguish $N$. ceranaefrom N. apisas the morphology of their spores is impossible to distinguish with $100 \%$ certainty by conventional microscopy. The rRNA gene sequence seems to be an excellent DNA barcodes (sensu Valentini et al., 2009) to differentiate among these and other microsporidian species (Klee et al., 2006), but not for intraspecific characterization of variants (O'Mahony et al.,
2007). Several studies suggested that the distinct effect of N.ceranae on individual and/or bee colony level reported in different geographic regions is strongly associated with intraspecific variability of $N$. ceranae (Higes et al., 2006, 2013; Maside et al., 2015; Branchiccela et al. 2016). The development and implementation of accurate molecular tools capable of characterizing Nosema genetic variants are still necessary to clarify this hypothesis. Recently, some authors provided new insights in this research context. Branchiccela et al. (2016) confirmed the existence of genetic variance in the $N$. ceranae genome, by inter-sequence single repetition (ISSR), allowing the identification of a conserved genetic variant circulating in different countries. In addition, these authors also showed that the $A$. mellifera bee immune response triggered against different $N$. ceranae genetic variants might be different. Genetic variability of Nosema isolates from $A$. mellifera largely remains unknown worldwide, including in Romania. How ever, considering that in the present study was observed similarities in the effect of $N$. ceranae infection in the monitored bee colonies, we would not be expecting to find great variability among the isolates obtained.

\section{Conclusions}

In conclusion, the combination of conventional microscopy and PCR/DNA sequencing demonstrated to be an effective method for Nosema spp. detection in $A$. mellifera honeybee, and evaluation of the prevalence of this pathogen in apiaries from three Southwestern counties of Romania. In addition, the exclusive presence of N.ceranae in all the monitored apiaries suggests the dominance of this species and its capacity to replace $N$. apis throughout time, in this region. Nosema ceranae is clearly a novel, emergent pathogen of $A$. mellifera with potentially very serious effects on the individual and honeybees colonies in Romania. Data obtained provide importantinformation on $N$. ceranaegeographic prevalence and distribution, and on its impact at colony level and/or its role in colony losses. The presentstudy intends to contribute to highlight the importance of implementing prevention, treatment and control measures of honeybee nosemosis, in Romania. Additional epidemiological studies mostly based on specific-molecular tools, are needed to carry out a larger and detailed survey, involving the status of Nosema spp. and its honeybee host in apiaries of all the different regions of Romanian Territory. 


\section{References}

1.AGRIPINA, S., VASILICA, S., RADOI, I., TAPALOAGA, D., TANASE, P., VICTOR, C. (2017) Evaluation of results in research made in order to obtain a phytotherapeutic product for the prophylaxis and fight against Nosema in bees The EuroBiotech Journal 1.

2.ALAUX, C., CRAUSER, D., PIOZ, M., SAULNIER, C., LE CONTE, Y. (2014) Parasitic and immune modulation of flight activity in honey bees tracked with optical counters. J. Exp. Biol. 217, 3416-3424 3.ALTSCHUL, S.F., MADDEN, T.L., SCHAFFER, A.A., ZHANG, J., ZHANG, Z., MILLER, W., LIPMAN, D.J . (1997) Gapped BLAST and PSI-BLAST: a new generation of protein database search programs. Nucleic Acids Res. 25, 3389-3402

4.ANSARI, M.J., AL-GHAMDI, A., NURU, A., KHAN, K.A., ALATTAL, Y. (2017) Geographical distribution and molecular detection of Nosema ceranae from indigenous honey bees of Saudi Arabia. Saudi J. Biol. Sci. 24(5), 983-991

5.BAILEY L. (1955) The infection of the ventriculus of the adult honeybee by Nosema apis (Zander). Parasitology 45, 86-94

6.BLAZYTE-CERESKIENE, L., SKRODENYTË-ARBACIAUSKIENE, V., SANDRA RADZIUTE IRENA NEDVECKYTE, BUDA. V. (2016) Honey Bee Infection Caused by Nosema spp. in Lithuania. Journal of Apicultural Research, 60(2), 77-87

7.BUDGE, G. (2008) Nosema ceranae. Bee Craft. January, 7-8 8.BRANCHICCELA, B., ARREDONDO, D., HIGES, M., INVERNIZZI, C., MARTIN-HERNANDEZ, R., TOMASCO I., ZUNINO, P., ANTUNEZ, K. (2017). Characterization of Nosema ceranae Genetic Variants from Different Geographic Origins. Microb. Ecol. 73(4), 978-987

9.CHAIMANEE V., WARRIT N., CHANTAWANNAKUL P., 2010. Infections of Nosema ceranae in four different honeybee species. J. Invertebr Pathol. 105(2), 207-10.

10.CHAUZAT MARIE-PIERRE, MARIANO HIGES, RAQUEL MARTÍNHERNÁNDEZ, ARANZAZU MEANA, NICOLAS COUGOULE, JEAN-PAUL FAUCON. Presence of Nosema ceranae in Frenchhoney bee colonies J ournal of Apicultural Research 46(2): 127-128 (2007)

11.CHEN, Y. W., CHUNG, W. P., WANG, C. H., SOLTER, L. F., AND HUANG, W. F. (2012). Nosema ceranae infection intensity highly correlates with temperature. J. Invertebr. Pathol. 111, 264-267.

12.CHEN, Y.P., EVANS, J.D., MURPHY, C.A., GUTELL, R., ZUKER, M., GUNDERSEN,RINDAL,D.E.,PETTIS, J.S.(2009)Morphological,molecular,and phylogenetic characterization of Nosema ceranae, a microsporidian parasite isolated from the European honey bee, Apis mellifera, J. Euk. Microb. 56, 142-147

13.CHEN, Y., EVANS, J. D., SMITH, I. B., PETTIS, J. S. (2008) Nosema ceranae is a long-present and wide-spread microsporidian infection of the European honeyb bee(Apis mellifera) in the United States. J. Invertebr. Pathol. 97, 186-188

14.CHEN, Y.P., HUANG, Z.Y. (2010) Nosema ceranae, a newly identied pathogen of Apis mellifera in the USA and Asia. Apidologie, Springer Verlag,41(3), <10.1051/apido /2010021> <hal00892100>

15.CHEMUROT, M., DE SMET, L., BRUNAIN, M., DE RYCKE, R., DE GRAAF , D.C. (2017) Nosema neumanni n. sp. (Microsporidia, Nosematidae), a new microsporidian parasite of honeybees, Apis mellifera in Uganda. Eur. J. Protistol. 61(Pt A, 13-19.

16.COPLEY, T.R., JABAJI S.H. (2012). Honeybee glands as possible infection reservoirsof Nosema ceranae and Nosema apis in naturally infected forager bees. J. Appl.

Microbiol. 112(1), 15-24

17.CORNMAN, R. S., TARPY D. R., CHEN, Y., JEFFREY, L., LOPEZ, D., PETTIS, J. S., ET. (2012) Pathogen webs in collapsing honey bee colonies. PLOS ONE 7, e43562

18.COROIAN, C.O., MUNOZ, I., SCHLUNS, E.A., PANITI-TELEKY, O.R., ERLER, S., FURDUI, E.M., MARGHITAS, L.A., DEZMIREAN, D.S., SCHLUNS, H., DE LA RUA, .P, MORITZ, R.F. (2014) Climate rather than geography separates two European honeybee subspecies.Mol. Ecol. 23(9), 2353-61.

19.COX-FOSTER, D.L., CONLAN, S., HOLMES, E.C., PALACIO, G., EVANS, J.D., MORAN, N.A., QUAN, P.L., BRIESE, T., HORNIG, M., GEISER,
D.M., MARTINSON, V., VANENGELSDORP, D., KALKSTEIN, A.L., DRYSDALE, A., HUI, J., ZHAI, J., CUI, L., HUTCHINSON, S.K., SIMONS, J.F., EGOLM, M., PETTIS, J.S., LIPKIN, W.I. (2007) A metagenomic survey of microbes in honey bee colony collapse disorder. Science 318, 283- 287

20.DELANEY, D.A., MEIXNER, M. D., SCHIFF, N.M., SHEPPARD, W.S. (2009) Genetic characterization of commercial honey bee (Hymenoptera: Apidae) populations in the United States by using mitochondrial and microsatellite markers. Ann. Entomol. Soc. Am. $102,666-673$

21.DUSSAUBAT,C.,MAISONNASSE,A., CRAUSER,D.,BESLAY, D., COSTAGLIOLA, G., SOUBEYRAND, S., ET AL. (2013) Flight behavior and pheromone changes associated to Nosema ceranae infection of oney bee workers (Apis mellifera) in field conditions. J. Invertebr. Pathol. 113, 42-51

22.EMSEN, B., GUZMAN-NOVOA, E., HAMIDUZZAMAN, M.M., ECCLES, L., LACEY, B., RUIZ- PÉREZ, R.A., NASR, M. (2016) Higher prevalence and levels of Nosema ceranae than Nosema apis infections in Canadian honey bee colonies. Parasitol. Res. 115(1),175-81

23.EVANS, J.D., SCHWARZ, R.S. (2011). Bees brought to their knees: microbes affecting honey bee health. Trends Microbiol. 19, 614-620 24.FENOY, S., RUEDA, C., HIGES, M., MARTÍN-HERNANDEZ, R., DEL AGUILA, C. (2009) High-level resistance of Nosema ceranae, a parasite of the honeybee, to temperature and desiccation. Appl. Environ. Microbiol. 75, 6886-6889

25.FERROGLIO, E., ZANET, S., PERALDO, N., TACHIS, E., TRISCIUOGLIO, A., LAURINO, D., PORPORATOM. (2013) Nosema ceranae has been infecting honey bees Apis mellifera in Italy since at least 1993. J. Apicult. Res. 52, 60-61

26.*** FOOD AND AGRICULTURE ORGANIZATION OF THE UNITED NATIONS (FAO), 2009. FAOSTAT.http://faostat.fao.org. (accessed March 2018)

27.FORSGREN, E., AND FRIES I. (2010) Comparative virulence of Nosema ceranae and Nosema apis in individual European honey bees. Vet. Parasitol. 170, 212-217

28.FORSGREN, E., FRIES, I. (2013) Temporal study of Nosema spp. in a cold climate. Environ. Microbiol. Rep. 5, 78-82

29.FRIES, I. (2010) Nosema ceranae in European honey bees (Apis mellifera). J Invertebr Pathol. 103 (1), S73-79. Review

30.FRIES, I., FENG, F., DA SILVA, A., SLEMENDA, S.B., PIENIAZEK, N.J . (1996) Nosema ceranae n. sp. (Microspora, Nosematidae), morphological and molecular characterization of a microsporidian parasite of the Asian honey bee Apis cerana (Hymenoptera, Apidae). Eur. Protistol. 32, 356-365

31.FRIE,SI., FORSGREN, E. (2008) UNDERSOKNING AV SPRIDNINGEN AV NOSEMA CERANAE I SVERIGE. Investigation of the distribution of Nosema ceranae in Sweden Bitidningen 107, 26-27.

32.FRIES, I., CHAUZAT, M.P., CHEN, Y.P., DOUBLET, V., GENERSCH, E., GISDER, S., et al. (2013) Standard methods for Nosema research. J. Apicult. Res. 52, 1-28

33.FRIES, I., MARTIN, R., MEANA, A., GARCIA-PALENCIA, P., HIGES, M. (2006) Natural infections of Nosema ceranae in European honey bees, J. Apic. Res. 45, 230-233

34.GENERSCH, E., VON DEROHE, W., KAATZ, H., SCHROEDER, A.,OTTEN, C., BÜCHLE,R R., ET al. (2010) The German bee monitoring project: a long term study to understand periodically high winter losses of honey bee colonies. Apidologie 41, 332-352 35.GIERSCH, T., BERG, T., GALEA, F., HORNITZKY, M. (2009) Nosema ceranae infects honey bees (Apis mellifera) and contaminates honey in Australia, Apidologie 40,117-123

36.GISDER, S., HEDTKE, K., MÖCKEL, N., FRIELITZ, M. C., LINDE, A., AND GENERSCH, E. (2010) Five-year cohort study of Nosema spp. in Germany: does climate shape virulence and assertiveness of Nosema ceranae? Appl. Environ. Microbiol. 76, 3032-3038

37.GISDER, S., SCHÜLER, V., HORCHLER, L.L., GROT,H D., GENERSCH, E. (2017) Long-Term Temporal Trends of Nosema spp. Infection Prevalence in Northeast Germany:Continuous Spread of Nosema ceranae, an Emerging Pathogen of Honey Bees (Apis mellifera), but 
No General Replacement of Nosema apis. Front Cell Infect.Microbiol. 6, 7,

38.GOBLIRSCH, M., HUANG, Z.Y., SPIVAK, M. (2013) Physiological and behavioral changes in honey bees (Apis mellifera) induced by Nosema ceranae Infection. PLoS One 8, e58165

39.GUERRERO-MOLINA, C., CORREA-BENITTEZ, A., HAMIDUZZAMAN, M.M., GUZMAN-NOVOA, E. (2016) Nosema ceranae is an old resident of honey bee (Apis mellifera) colonies in Mexico, causing infection levels of one million spores per bee or higher during summer and fall. J. Invertebr. Pathol. 141,38-40

40.HADDAD, N.J. (2014) First detection of Nosema ceranae in J ordan. European Scientific J ournal 10(33), ISSN: 1857 - 7881 (Print) e - ISSN 1857- 7431

41.HIGES,M.,GARCIA-PALENCIA,P.,MARTIN-HERNANDEZ, R., MEAN, A.,(2007) Experimental infection of Apis mellifera honeybees with Nosema ceranae (Microsporidia). J. Invertebr. Pathol. 94, 211-217 42.HIGES, M., MEANA, A., BARTOLOMÉ, C., BOTÍAS, C., MARTÍNHERNANDEZ, R. (2013) Nosema ceranae ( M i c r o s p o r i d i a ) , a controversial 21st century honey bee pathogen.Environ Microbiol Rep. 2013 Feb;5(1):17-29. doi:10.1111/1758-2229.12024. Epub Jan 18. Review

43.HIGES, M., MARTIN-HERNANDEZ, R., BOTIAS, C., BAILON, E.G., GONZALEZ-PORTO, A.V.,BARRIOS, L., DEL NOZAL, D.J., BERNAL, J.L., JIMENEZ, J.J ., PALENCIA, P.G., MEANA, A.(2008) How natural infection by Nosema ceranae causes honeybee colony collapse.Environ. Microbiol. 10, 2659-2668

44.HIGES, M., MARTIN-HERNANDEZ, R., MEANA A. (2010) Nosema ceranae in Europe: an emergent type C nosemosis. Apidologie. 41, 375-392

45.HIGES, M., MARTIN-HERNANDEZ, R., MEANA, A. (2006) Nosema ceranae, a new microsporidian parasite in honey bees in Europe. J. Invertebr. Pathol. 92, 93-95

46.HUANG, W. F., JIANG, J. H., CHEN, Y. W., WANG, C.H. (2007) A Nosema ceranae isolate from the honeybee Apis mellifera. Apidologie 38, 30-37

47.HUANG, W.F., SOLTER, L., ARONSTEIN, K., HUANG, Z. (2015) Infectivity and virulence of Nosema ceranae and Nosema apis in commercially available North American honey bees. J. Invertebr. Pathol. 124, 107-113

48.INVERNIZZI, C., ABUD, C., TOMASCO, I.H., HARRIET, J., RAMALLO, G., CAMPA, J., KATZ, H., GARDIOL, G., MENDOZA, Y. (2009) Presence of Nosema ceranae in honeybees (Apis mellifera) in Uruguay. J Invertebr Pathol. 101(2), 150-153

49.KLEIN, A.M., VAISSIERE, B.E., CANE, J.H., STEFFAN-DEWENTER, I., CUNNINGHAM, S.A.,KREMEN, C., TSCHARNTKE, T. (2007) Importance of pollinators in changing landscapes for world crops. Proc. Roy. Soc. Lond. B. 274, 303-313

50.KLEE, J., BESANA, A.M., GENERSCH, E., GISDER ,S.,NANETT, A., TAM D.Q., ET AL. (2007)Widespread dispersal of the microsporidian Nosema ceranae, an emergent pathogen of the western honey bee, Apis mellifera. J. Invertebr. Pathol. 96, 1-10

51.KLEE, J., TAY, W.T., PAXTON, R.J . (2006) Specific and sensitive detection of Nosema bombi (Microsporidia: Nosematidae) in bumble bees (Bombus spp.; Hymenoptera:Apidae) by PCR of partial rRNA gene sequences. J. Invertebr. Pathol. 91, 98-104

52.LOBO, M.L., SILVEIRA, H., RAMOS, S., XIAO, L., MATOS, O. (2006) Characterization of a pathogen related to Vavraia culicis detected in a laboratory colony of Anopheles stephensi. J. Eukaryot Microbiol. 53, Suppl 1, S65-67.

53.LOBO, M.L., XIAO, L., CAMA, V., MAGALHAES, N., ANTUNES, F., MATOS, 0. (2006)

Identification of potentially human-pathogenic Enterocytozoon bieneusi genotypesin various birds. Appl. Environ. Microbiol. 72(11),7380-7382

54.MAYACK, C., NAUG, D. (2009) Energetic stress in the honeybee Apis mellifera from Nosema ceranae infection. J. Invertebr. Pathol. $100,185-188$
55.MARTIN-HERNANDEZ, R., BOTIAS, C., BAILON, E.G., MARTINEZSALVADOR, A., PRIETO, L.,MEANA, A., ET AL. (2012) Microsporidia infecting Apis mellifera: coexistence or competition. Is Nosema ceranae replacing Nosema apis? Environ. Microbiol. 14, 2127-2138 56.MARTIN-HERNANDEZ, R., MEANA, A., PRIETO, L., SALVADOR, A.M., GARRIDO-BAILON, E.,HIGES, M. (2007) Outcome of colonization of Apis mellifera by Nosema ceranae.Appl. Environ. Microbiol. 73, 63316338

57.MARTIN-HERNANDEZ, R., MEANA， A., GARCIA-PALENCIA，P., MARIN, P., BOTIAS, C.,GARRIDO-BAILON, E., ET AL. (2009) Effect of temperature on the biotic potential of honeybee microsporidia. Appl. Environ. Microbiol. 75, 2554-2557

58.MARTINEZ, J., LEAL, G., CONGET, P. (2012) Nosema ceranae an emergent pathogen ofApis mellifera in Chile. Parasitol Res. 111(2), 601-607

59.MASIDE, X., GOMEZ-MORACHO, T., JARA, L., MARTIN-HERNANDEZ, R., DE LA RUA, P.,HIGES, M., BARTOLOMÉ, C. (2015) Population Genetics of Nosema apis and Nosema ceranae: One Host (Apis mellifera) and Two Different Histories. PLoS One 31,10(12), e0145609 60.MCGREGOR, S.E. (1976) Insect Pollination of Cultivated Crop Plants. US Department of Agriculture, Washington, DC.

61.MILBRATH, M.O., VAN TRAN, T., HUANG, W. F., SOLTER, L. F., TARPY, D. R., LAWRENCE,F., ET AL. (2015) Comparative virulence and competition between Nosema apis and Nosema ceranae in honey bees (Apis mellifera). J. Invertebr. Pathol. 125, 9-15

62.MUZ, M.N., GIRISGIN, A.O., MUZ ,D., AYDIN, L. (2010) Molecular detection of Nosema ceranae and Nosema apis infections in Turkish apiaries with collapsed colonies. J Apic Res. 49(4), 342

63.NATSOPOULOU, M. E., MCMAHON, D. P., DOUBLET, V., BRYDEN, J., PAXTON, R. J. (2015) Interspecific competition in honey bee intracellular gut parasites is asymmetric and favours the spread of an emerging infectious disease. Proc. R. Soc. B. 282, 20141896 64.ODNOSUM, H. V. (2017) Distribution of the Nosema ceranae (Microspora),Nosematidae) in the apiaries in Ukraine. Vestnik zoologii, 51(2), 161-166 OIE. Nosemosis of honey bees (NB: Version adopted in May 2013). In: Manual of Diagnostic Tests and Vaccines for Terrestrial Animals. 2014. Available: http://www.oie.int/fileadmin/ Home/eng/Health_standards/tahm/2.02.04_NOSEMOSIS_FINAL.pdf. 65.0'MAHONY, E. M., TAY, W. T., PAXTON, R. J. (2007) Multiple rRNA variants in a single spore of the microsporidian Nosema bombi. J. Eukaryotic Microbiol. 54, 103-109

66.PAPINI, R., MANCIANTI, F., CANOVAI, R., COSCI, F., ROCCHIGIANI, G., BENELLI ,G.,CANALE, A. (2017) Prevalence of the microsporidian Nosema ceranae in honeybee (Apis mellifera) apiaries in Central Italy. Saudi J Biol Sci. 24(5), 979-982

67.PAXTON, R.J . (2010) Does infection by Nosema ceranae cause Colony Collapse Disorder in honey bees (Apis mellifera)? J. Apic. Res. 49, 80-84

68.PAXTON, R.J., KLEE, J., KORPELA, S., FRIES, I. (2007) Nosema ceranae has infected Apis mellifera in Europe since at least 1998 and may be more virulent than Nosema apis. Apidologie 38: 558-565 69.PETTIS. J. S., LICHTENBERG. E. M., ANDREE. M., STITZINGER. J., ROSE. R., VANENGELSDORP.D. (2013) Crop pollination exposes honey bees to pesticides which alters their susceptibility to the gut pathogen Nosema ceranae PLoS ONE 8, e70182.

70.RATNIEKS ,F. L.W., CARRECK N. L. (2010) Clarity on honey bee collapse? Science 327, 152-153

71.RUTTNER, F. (1988) Taxonomy and Biogeography of Honey Bees. Springer, Munich

72.SCHWARZ. R.S., HUANG. Q., EVANS, J.D. (2015. Hologenome theory and the honey bee pathosphere. Curr. Opinion Insect. Sci. 10, 1-7 73.SHUMKOVA, R., GEORGIEVA, A., RADOSLAVOV, G., SIRAKOVA, D., DZHEBIR, G., NEOV, B.,BOUGA, M., HRISTOV, P., PEER J . (2018). The first report of the prevalence of Nosema ceranae in Bulgaria. 31;6, e4252. doi: 10.7717/peerj.4252. eCollection 2018.

74.STEVANOVIC, J., SIMEUNOVIC, P., GAJIC, B., LAKIC, N., RADOVIC, D., FRIES, I., STANIMIROVIC, Z. (2013) Characteristics of Nosema ceranae infection in Serbian honey bee colonies. Apidologie $44,522-536$ 
75.STEVANOVIC, J., STANIMIROVIC, Z., GENERSCH, E., KOVACEVIC, S. R., LJUBENKOVIC, J.,RADAKOVIC, M., ET AL. (2011) Dominance of Nosema ceranae in honey bees in the Balkan countries in the absence of symptoms of colony collapse disorder. Apidologie 42 , 49-58

76.STEVANOVIC, J., SCHWARZ, R.S., VEJ NOVIC, B., EVANS, J.D., IRW IN, R.E., GLAVINIC, U.,STANIMIROVIC,Z.(2016) Species-specific diagnosticsof Apis melliferatrypanosomatids: A nine-year survey (2007-2015) for trypanosomatids and microsporidians in Serbian honey bees. J. Invertebr. Pathol. 139, 6-11

77.TAPASZTI, Z., FORGÁCH, P., KOVAGO, C., LASZLO (2009) First detection and dominance of Nosema ceranae in Hungarian honeybee colonies. Acta Veterinaria Hungarica 57 (3), 383-388

78.TEIXEIRA, E.W., SANTOS, L.G., SATTLER, A., MESSAGE, D., ALVES, M.L., MARTINS, M.F.,GRASSI-SELLA, M.L., FRANCOY, T.M. (2013). Nosema ceranae has been present in Brazil for more than three decades infecting Africanized honey bees. J. Invertebr.Pathol. 114(3), 250-254

79.TOPOLSKA, G., GAJ DA, A., HARTWIG, A., Polish honey bee colonyloss during the winter of 2007/2008. J. Apic. Sci. 52 (2), 95-104,

80.TRAVER, B.E., FELL, R.D. (2011) Prevalence and infection intensity of Nosema in honey bee (Apis mellifera L.) colonies in Virginia. J. Invertebr. Pathol. 107(1), 43-49

81.TRITSCHLER, M., RETSCHNIG, G., YANEZ, O., WILLIAMS, G.R., NEUMANN, P. (2017) Host sharing by the honey bee parasites Lotmaria passim and Nosema ceranae. Ecol Evol. 15, 7(6),1850-1857
82.TUNCA, R. I., OSKAY, D., GOSTERIT, A., TEKIN, O.K. (2016) Does Nosema ceranae Wipe Out Nosema apis in Turkey? Iran J. Parasitol.11(2), 259-264

83.VALENTINI, A., POMPANON, F., TABERLET, P. (2009) DNA barcoding for ecologists.Trends in Ecology and Evolution 24, 110-117

84.VANENGELSDORP, D., MEIXNER, M.D. (2010) A historical review of managed honey bee populations in Europe and the United States and the factors that may affect them. J . Invertebr. Pathol. 103, Suppl 1, S8095

85.WILLIAMS, G. R., SHAFER, A.B.A., ROGERS, R.E.L., SHUTLER, D., STEWART, D.T. (2008) First detection of Nosema ceranae, a microsporidian parasite of European honey bees (Apis mellifera), in Canada and central USA. J. Invertebr. Pathol. 97, 189-192

86.WHITAKER, J., SZALANSKI, A.L., KENCE, M. (2011) Molecular detection of Nosema ceranae and N. apis from Turkish honey bees. Apidologie 42, 174-80

87.YOSHIYAMA, M., KIMURA, K. (2011) Distribution of Nosema ceranae in the European honeybee, Apis mellifera in Japan. J. Invertebr. Pathol. 106(2), 263-267

88.YUCEL, B., GOGAROGLU, M. (2005) The impact of Nosema apis Z. infestation of honey bee (Apis mellifera L.) colonies after using different treatment methods and their effects on the population levels of workers and honey production on consecutive years. Pak. J. Biol. Sci. 8, 1142-1145

$\overline{\text { Manuscript received:22.07.2018 }}$ 